\title{
Evidence for foot orthoses for adults with flatfoot: a systematic review
}

\author{
Minettchen Herchenröder ${ }^{*}$ (D) Denise Wilfling ${ }^{\dagger}$ and Jost Steinhäuser
}

\begin{abstract}
Background: Flatfoot is characterised by the falling of the medial longitudinal arch, eversion of the hindfoot and abduction of the loaded forefoot. Furthermore, flatfoot leads to a variety of musculoskeletal symptoms in the lower extremity, such as knee or hip pain. The standard conservative treatment for flatfoot deformity is exercise therapy or treatment with foot orthoses. Foot orthoses are prescribed for various foot complaints. However, the evidence for the provision of foot orthoses is inconsistent. The aim of this systematic review is to synthesize the evidence of foot orthoses for adults with flatfoot.

Methods: A computerized search was conducted in August 2021, using the databases PubMed, Scopus, Pedro, Cochrane Library, and the Cochrane Central Register of Controlled Trials. Intervention studies of any design investigating the effects of foot orthoses were included, apart from case studies. Two independent reviewers assessed all search results to identify eligible studies and to assess their methodological quality.

Results: A total of 110 studies were identified through the database search. 12 studies met the inclusion criteria and were included in the review. These studies investigated prefabricated and custom-made foot orthoses, evaluating stance and plantar pressure during gait. The sample sizes of the identified studies ranged from 8 to 80 . In most of the studies, the methodological quality was low and a lack of information was frequently detected.

Conclusion: There is a lack of evidence on the effect of foot orthoses for flatfoot in adults. This review illustrates the importance of conducting randomized controlled trials and the comprehensive development of guidelines for the prescription of foot orthoses. Given the weak evidence available, the common prescription of foot orthoses is somewhat surprising.
\end{abstract}

Keywords: Foot orthoses, Shoe inserts, Orthotic devices, Orthotic insoles, Pes planus, Flatfoot, *adults

\section{Background}

Foot orthoses are prescribed for various foot complaints and pain [1-3]. Foot orthoses are a common prescription for flatfoot. Flatfoot is characterised by the falling of the medial longitudinal arch, eversion of the hindfoot and abduction of the loaded forefoot. Flatfeet may affect one or both feet $[4,5]$. Typical flatfoot symptoms include plantar fascia pain and Achilles tendonitis [6,7], ligamentous instability and

* Correspondence: minettchen.herchenroeder@uksh.de

Minettchen Herchenröder and Denise Wilfling Divided authorship Institute of Family Medicine, University of Lübeck, Ratzeburger Allee 160, 23562 Lübeck, Germany

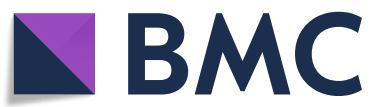

laxity [6], pain under weight loading, rapid fatigability and medial instability in the foot [8]. Furthermore, flatfoot can lead to a variety of musculoskeletal aches in the lower extremity, such as knee pain and hip pain $[9,10]$. In the United States five million Americans are currently diagnosed and living with flatfoot [11]. In the UK, the prevalence is estimated to be over $3 \%$ in women over 40 years old $[12,13]$. Furthermore, $10 \%$ of the geriatric population suffers from severe acquired flatfoot due to the degeneration of muscle mass and bone structure [14]. The standard conservative treatment for flatfoot deformity is exercise therapy or treatment with foot orthoses [15].

(c) The Author(s). 2021, corrected publication 2022. Open Access This article is licensed under a Creative Commons Attribution 4.0 International License, which permits use, sharing, adaptation, distribution and reproduction in any medium or format, as long as you give appropriate credit to the original author(s) and the source, provide a link to the Creative Commons licence, and indicate if changes were made. The images or other third party material in this article are included in the article's Creative Commons licence, unless indicated otherwise in a credit line to the material. If material is not included in the article's Creative Commons licence and your intended use is not permitted by statutory regulation or exceeds the permitted use, you will need to obtain permission directly from the copyright holder. To view a copy of this licence, visit http://creativecommons.org/ licenses/by/4.0/. The Creative Commons Public Domain Dedication waiver (http://creativecommons.org/publicdomain/zero/1. 0/) applies to the data made available in this article, unless otherwise stated in a credit line to the data. 
However, the effect of these varies and remains controversial [16-20].

In Germany, about 8\% (five million people) of patients with flatfoot symptoms get a foot orthoses prescription due to any indication. Consequently, there were increased costs in the year 2019 of 466.6 million euros for Statutory Health Insurance [21].

Foot orthoses are mainly prescribed by primary doctors and orthopaedic doctors. In addition, about $30 \%$ of primary doctors are general internal medicine physicians in Germany. These two groups have undergone different postgraduate training, e.g. internists are primarily inpatient-based with no surgical or orthopaedic training [22].

It seems like that there are currently no guidelines or checklists for the prescription of foot orthoses for flatfoot, other than those identified in one Delphi consensus study from Australia [23]. Accordingly, the prescription of foot orthoses for flatfoot is often inconsistent and ranges from a purely clinical based approach, to digital motion analysis $[24,25]$ and force plates $[8,26,27]$, to radiological examinations [28-33] or three-dimensional (3-D) imaging [34].

This study aims to systematically review and synthesize the current evidence of foot orthoses for flatfoot.

\section{Methods}

Established methodological frameworks for systematic evidence syntheses [35] and the Preferred Reporting Items for Systematic Reviews and Meta-analyses (PRISMA) [36] were used in order to present results in a full and transparent way and to minimise bias.

No study protocol was registered.

\section{Search methodology}

The search strategy was defined by the principles of a systematic search, using the PICO scheme and implied free-text keywords and medical subject headings (Mesh terms) performed by two reviewers. A computerized search was conducted in August 2021, using the databases Medline via PubMed, Scopus, PEDro, Cochrane Library and Cochrane Central Register of Controlled Trials. Major search terms for all databases are represented in Table S1.

Relevant gray literature was derived via Google Scholar. Furthermore, we checked reference lists of included studies, and relevant reviews were identified through the search. The results of the search were imported into the web service Covidence (www. covidence.org), which was used for the entire review process.

\section{Study selection}

All intervention studies evaluating any kind of foot orthoses or inserts for flatfoot were eligible for inclusion, with the exception of case studies. Studies evaluating surgical interventions were excluded. We included scientific articles published in peer reviewed journals in English and German. To get the largest possible number of studies, no limitations of the publication year were applied. As an inclusion criterion, studies must have determined outcomes in the form of patient-reported, clinician-reported or laboratory-based measurements. All inclusion and exclusion criteria are shown in Table 1.

Two independent reviewers (MH, DW) assessed titles and abstracts from all search results to identify eligible studies. After potentially relevant articles were selected, full reports were obtained and inclusion and exclusion criteria were assessed. Intervention studies evaluating any kind of foot orthoses for adults with flatfoot were included. Studies evaluating surgical interventions were excluded.

Any disagreement on the eligibility of studies was resolved through discussion to reach consensus or, if required, by involving a third experienced review author (JS).

\section{Data extraction and methodological quality}

Data from each study included in this review was independently extracted by two reviewers (MH, DW). In the event of disagreements or discrepancies, a third review author was involved to reach consensus. Data were extracted into standardised tables, including author, publication year, study design, participants, interventions, setting, outcomes, measurements and main findings according to the Cochrane Handbook for Systematic Reviews of Interventions [35].

The methodological quality of all of the included studies was assessed using the Cochrane Risk of Bias tool for randomized controlled trials (RCTs) [35] and the ROBINS-I tool for all other study designs. Two reviewers $(\mathrm{MH}, \mathrm{DW})$ independently assessed the methodological quality of the studies included in order to identify any potential sources of bias.

\section{Results \\ Description of included studies}

The initial search identified 110 studies. After removing duplicates, 97 studies were investigated. 72 studies were excluded after title and abstract screening. 24 full texts were reviewed and finally 12 studies were included in the study. Two ongoing studies were also included [37, 38]. The process of study selection is presented in Fig. 1.

A total of 170 participants were included. The sample sizes of the included studies ranged from 8 [34] to 80 
Table 1 Inclusion and exclusion criteria

\begin{tabular}{ll}
\hline Inclusion & Exclusion \\
\hline $\begin{array}{l}\text { English-language articles } \\
\text { German-language articles }\end{array}$ & Articles in other languages \\
Scientific articles published in peer-reviewed journals & Popular articles \\
All kind of intervention studies & Study summaries \\
All kid of shoe insoles & Case reports \\
Adult patients with flatfoot & Systematic reviews \\
Outcomes measured with any kind of tool & Other interventions \\
All settings & children \\
\hline
\end{tabular}

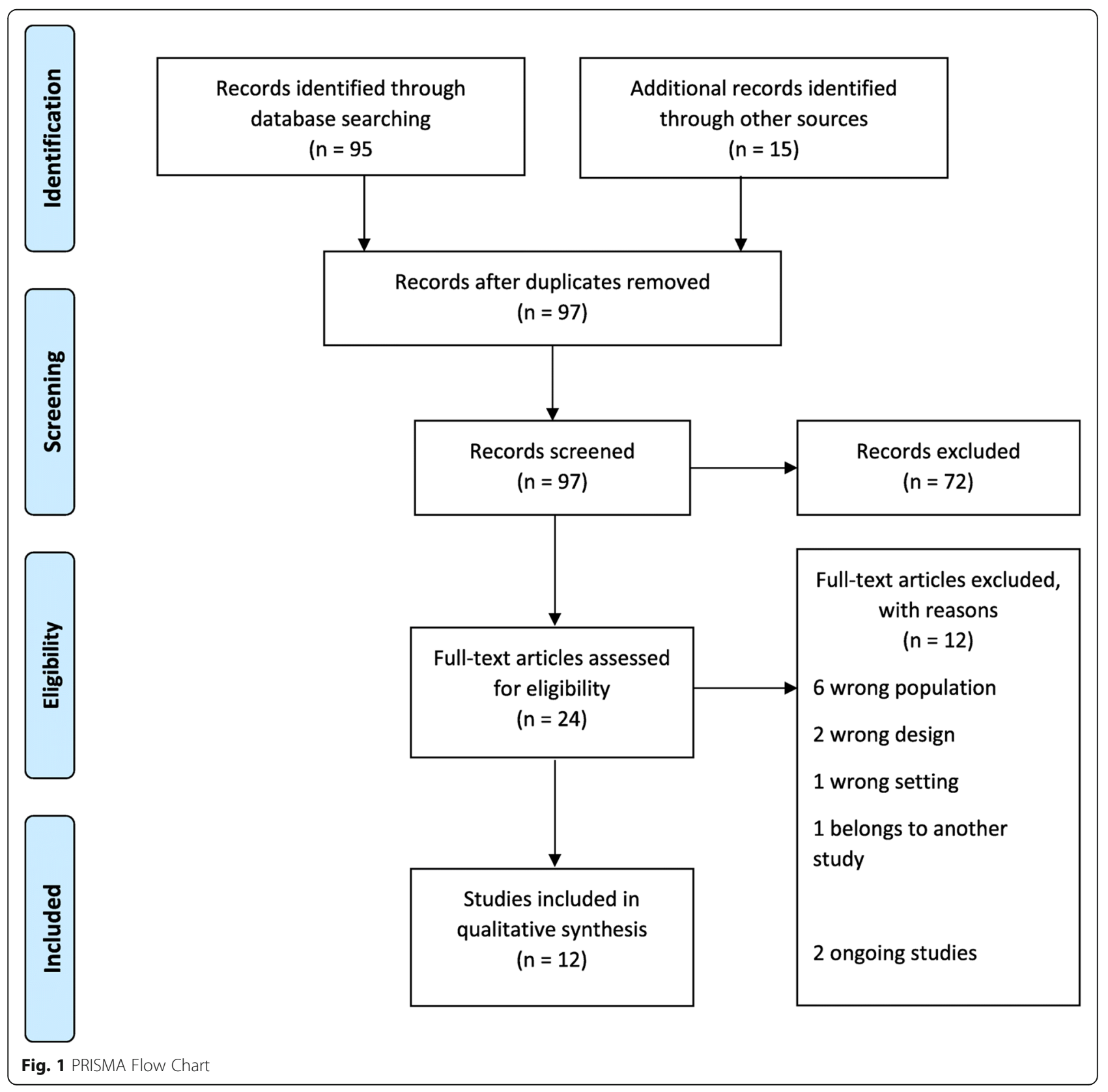


[39]. Of the 12 included studies, most were repeatedmeasures intervention studies $(n=9)$ [16, 34, 40-46]. Other studies used a randomised-controlled design [39], before-after design [47] or a non- randomised controlled design [48].

Studies were conducted in Asia [16, 34, 39, 43-46, 48], Australia [42], the United States [41], Iran [40] and Turkey [47]. Most participants were young adults aged between 18 and 45 years $($ Mean $=31.5)$ [16, 34, 41, 42, 46-48]. Two studies recruited only male participants aged 20 and 22 years (Mean = 21) [40, 45] and three studies recruited only college students [43-45]. Two studies $[43,44]$ gave no information about age.

Flatfoot was diagnosed differently in the included studies. Chen et al. [16] diagnosed flatfoot by static foot posture, Kido et al. [34] based their diagnosis on radiographs under static loading conditions and Murley et al. [42] investigated their participants radiologically and applied an arch index. Tang et al. [48] diagnosed flatfoot by measuring the arch index described by Cavanagh and Rodgers [49]. Xu et al. [39] diagnosed flatfoot by foot posture index (FPI). Other studies gave no information about flatfoot diagnosis [40, 41, 43-47].

Only one study [47] described the study setting. None of the studies provided information on wearing time or when the outcomes were measured. Study characteristics are summarized in Table 2.

\section{Methodological quality}

For the randomised-controlled study of $\mathrm{Xu}$ et al. 2019, we judged the risk of bias as low in all items according to the Cochrane risk of bias tool for randomised controlled trials [50]. We were unable to judge the overall risk of bias for the other included studies because of a lack of information in the study reports. There is no clear indication that the studies are at serious or critical risk of bias and there was a lack of information in one or more key domains of bias [51]. None of the included studies [16, 34, 40-44, 46-48] gave information about confounding, selection of participants, deviations from intended interventions as well as selection of reported results. In only two studies $[47,48]$ the risk of bias due to missing data was determined to be low because outcome data was reported for all study participants. In other studies, [16, 34, 40-44, 46] it was unclear if outcome data included data from all participants. The risk of bias in classification of intervention was judged to be low in all studies $[16,34,40-44,46-48]$ because intervention groups were clearly defined. All studies [16, 34, 40-44, 46-48] showed a low risk of bias in measurement of outcomes because studies used objective outcome measurements. Results of the risk of bias assessment are summarized in Table 3.

\section{Measurements}

Most studies [16, 34, 47, 48] measured the effect of foot orthoses via 3-D motion capture. Chen et al. [16] used eight cameras under three conditions: walking barefoot, walking with shoes only and walking with shoes and foot orthoses. A motion analysis system was used by Tang et al. [48] to measure the effect of foot orthoses under the same conditions as Chen et al. Kido et al. [16, 34] used computed tomography. Acak [47] used a podoscope device to make images of the soles of feet. Han et al. [45] used 10 cameras under three conditions: walking with normal foot orthoses, foot orthoses with only arch support function and foot orthoses with both arch support and cushion pads for shock absorbing functions.

Pressure measurement plates were used in four studies [39-41, 46]. Miller et al. [41] conducted ten trials with and without foot orthoses. Aminian et al. [40] measured three conditions: wearing the shoe only, wearing the shoe with prefabricated foot orthoses and wearing the shoe with proprioceptive foot orthoses. Xu et al. [39] measured three conditions: barefoot, with 3-D and standardized foot orthoses. Jiang et al. [46] measured three different conditions: using an orthotic insole, a flat foot insole and 3-D printed insole. Two studies [43, 44], used imaging as well as pressure plates. In Murley et al. [42], imaging and electromyogram were conducted at baseline. After 12 days, four conditions were investigated: barefoot, walking with shoe only, walking with prefabricated foot orthoses and with 20 degree inverted customized foot orthoses.

\section{Outcome measures}

All included studies used different outcome measures. None of the studies reported an adverse event.

\section{Plantar pressure assessment}

Aminian et al. [40] measured plantar pressure in the shoe at the medial and lateral heel, medial and lateral midfoot and first, second, third, fourth and fifth rays. For the proprioceptive orthosis, the maximum force was significantly reduced in the medial midfoot, and plantar pressure was significantly increased in the second and third rays compared to the shoe only condition. Similarly, Jiang et al. [46] measured plantar pressure during walking at slow, normal and fast gait speeds on the treadmill at the hindfoot and midfoot while wearing 3-D foot orthoses (PPRI), foot orthoses and flat foot orthoses. The force on the rear and midfoot was significantly increased when wearing flat foot orthoses compared to PPRI and foot orthoses. In addition, the contact area at slow and normal speed in the midfoot area was smaller with PPRI compared to flat foot orthoses. In contrast Park et al. [43] investigated the change in pelvic angle using foot orthoses and reported a significant decrease 
Table 2 Characteristics of included studies

\begin{tabular}{|c|c|c|c|c|c|c|}
\hline $\begin{array}{l}\text { Author/ } \\
\text { year/ } \\
\text { country }\end{array}$ & Design & Population & Intervention & Setting & Outcomes/Measurement & Main results \\
\hline $\begin{array}{l}\text { Acak } \\
2020 \\
\text { (Turkey) }\end{array}$ & $\begin{array}{l}\text { Before-after } \\
\text { study }\end{array}$ & $\begin{array}{l}34 \text { participants } \\
\text { (17 male) with } \\
\text { pes planus } \\
\text { complaints } \\
\text { Age: } 18-28 \text { years }\end{array}$ & $\begin{array}{l}\text { Individually designed } \\
\frac{\text { insoles: }}{1 \mathrm{~mm} \text { thick stainless }} \\
\text { chrome steel covered with } \\
3 \mathrm{~mm} \text { thick antibacterial } \\
\text { leather }\end{array}$ & $\begin{array}{l}\text { Orthopedics and } \\
\text { Traumatology } \\
\text { Department of } \\
\text { Turgut Ozal } \\
\text { Medical Center } \\
\text { in Inonu } \\
\text { University }\end{array}$ & $\begin{array}{l}\text { Outcomes: } \\
\text { Height, weight, percent } \\
\text { body fat, } 30 \mathrm{~m} \text { sprint test, } \\
\text { vertical jump, } 12 \text { min } \\
\text { Cooper test and Visual } \\
\text { Analog Scale (VAS) } \\
\text { Measurement: } \\
\text { Image of the soles of feet } \\
\text { were obtained by using } \\
\text { the podoscope device. }\end{array}$ & $\begin{array}{l}\text { Statistically significant } \\
\text { differences found in pre- } \\
\text { and post-test results in } \\
\text { weight, BMl, } 30 \mathrm{~m} \text { run, ver- } \\
\text { tical jump, } 12 \text { min Cooper } \\
\text { run and VAS }\end{array}$ \\
\hline $\begin{array}{l}\text { Aminian } \\
\text { et al. } \\
2013 \\
\text { (Iran) }\end{array}$ & $\begin{array}{l}\text { Repeated- } \\
\text { measures } \\
\text { intervention } \\
\text { studies }\end{array}$ & $\begin{array}{l}12 \text { participants } \\
(12 \text { male) with } \\
\text { flexible flatfoot } \\
\text { Age: } 22.25( \pm \\
1.54)\end{array}$ & $\begin{array}{l}\text { Prefabricated orthosis: } \\
\text { commercially available, full } \\
\text { length and made of two } \\
\text { layers: ethyl vinyl acetate } \\
\text { at the bottom layer and } 1 \\
\mathrm{~mm} \text { thick leather layer on } \\
\text { the top. } \\
\text { Proprioceptive orthosis: } \\
\text { made of rubber and } \\
\text { covered by cloth, } 2 \mathrm{~mm} \\
\text { thick insole with no arch } \\
\text { support; } 3 \mathrm{~mm} \text { wedge as } \\
\text { an elevation area } \\
\text { extending from the }\end{array}$ & No information & $\begin{array}{l}\text { Outcomes: } \\
\text { In-shoe plantar pressure } \\
\text { (medial heel, lateral heel, } \\
\text { medial midfoot, lateral } \\
\text { midfoot, first ray, second } \\
\text { and third rays, fourth and } \\
\text { fifth rays) } \\
\text { Measurement: } \\
\text { Pedar-X system under } 3 \\
\text { conditions (wearing the } \\
\text { shoe only, wearing the } \\
\text { shoe with prefabricated } \\
\text { insole, wearing the shoe } \\
\text { with proprioceptive insole) }\end{array}$ & $\begin{array}{l}\text { Proprioceptive insoles: } \\
\text { maximum force was } \\
\text { significantly reduced in } \\
\text { medial midfoot, and } \\
\text { plantar pressure was } \\
\text { significantly increased in } \\
\text { the second and third rays } \\
\text { compared to the shoe } \\
\text { only condition. } \\
\text { Prefabricated insole: } \\
\text { maximum force was } \\
\text { significantly higher in } \\
\text { midfoot area compared to } \\
\text { the other conditions }\end{array}$ \\
\hline
\end{tabular}

\begin{tabular}{|c|c|c|c|}
\hline $\begin{array}{l}\text { Chen } \\
\text { et al. } \\
2010 \\
\text { (Taiwan) }\end{array}$ & $\begin{array}{l}\text { Repeated- } \\
\text { measures } \\
\text { intervention } \\
\text { studies }\end{array}$ & $\begin{array}{l}11 \text { participants } \\
\text { (6 male) with } \\
\text { flatfoot } \\
\text { Age: } 45.9 \text { ( } \pm \\
\text { 15.66) }\end{array}$ & $\begin{array}{l}\text { Insoles: custom made of } \\
\text { vinyl-acetate and } 12 \pm 3 \% \\
\text { far-infrared nanopowders } \\
\text { Shoes: } \\
\text { custom made of rubber } \\
\text { and PU }\end{array}$ \\
\hline
\end{tabular}

Han et al. Repeated2019 measures (South intervention Korea) studies

\begin{tabular}{|c|c|c|c|}
\hline $\begin{array}{l}\text { Jiang } \\
\text { et al. } \\
2021 \\
\text { (China) }\end{array}$ & $\begin{array}{l}\text { Repeated- } \\
\text { measures } \\
\text { intervention } \\
\text { studies }\end{array}$ & $\begin{array}{l}10 \text { participations } \\
(8 \text { male, } 2 \\
\text { females } \\
\text { Age: } 30 \text { years } \\
\text { with flexible } \\
\text { flatfoot }\end{array}$ & $\begin{array}{l}\text { Three different insoles: } \\
\text { Type A: the insole was } \\
\text { obtained by 3D printing } \\
\text { from the plantar pressure } \\
\text { (PPRI) } \\
\text { Type B: } \\
\text { Orthotic insole }\end{array}$ \\
\hline
\end{tabular}

28 participants Three different insoles: (male college The normal insoles were students) with used as an experimental flatfoot Age: $20.29( \pm$ $0.46)$ control without arch support function Type A insole

Weight: 70.43 ( \pm With only arch support 4.15) $\mathrm{kg} \quad$ function Height: 1.75 ( $\pm \quad$ Type B insole $3.55) \mathrm{cm}$ With both arch support and cushion pads for shock absorbing functions Type A and B Hardness and foot arch descent $45^{\circ}$

No Information

Outcomes

Plantar pressure stance time, stride frequency and peak pressure in each area of the sole and plantar condistribution Measurement
Walking with shoes and insoles and walking with shoes: increased the peak ankle dorsiflexion angle and moment, reduced the peak ankle plantarflexion angle and moment, increased the peak knee varus moment.

Effects of the orthoses on knee and hip were minimal and no significant differences were observed between walking with shoes and insoles and walking with shoes.

Insoles A and B show significantly less rearfoot ankle movement than the normal insole.

Force on the hindfoot and midfoot increased significantly when wearing flat insoles compared to PPRI and orthopedic insoles.

Contact area at slow and 
Table 2 Characteristics of included studies (Continued)

\begin{tabular}{|c|c|c|c|}
\hline $\begin{array}{l}\text { Author/ } \\
\text { year/ } \\
\text { country }\end{array}$ & Design & Population & Intervention \\
\hline & & & $\frac{\text { Type C }}{\text { Flat insole }}$ \\
\hline $\begin{array}{l}\text { Kido et al. } \\
2014 \\
\text { (Japan) }\end{array}$ & $\begin{array}{l}\text { Repeated- } \\
\text { measures } \\
\text { intervention } \\
\text { studies }\end{array}$ & $\begin{array}{l}8 \text { participants (4 } \\
\text { male, Age } 29- \\
38 ; 4 \text { females, } \\
\text { Age 26-38) with } \\
\text { mild flatfoot } \\
\text { deformity }\end{array}$ & $\begin{array}{l}\text { Accessory insoles } \\
\text { Therapeutic insoles: } \\
\text { deformity: made using a } \\
\text { CAD system (Pedcad Insole } \\
\text { Designer; Pedcad, } \\
\text { Oberkochen, Germany), } \\
\text { designed to raise the } \\
\text { medial longitudinal arch } \\
\text { by } 10 \mathrm{~mm} \text { with a } 5 \mathrm{~mm} \\
\text { inner wedge, particularly } \\
\text { reducing the burden of } \\
\text { the posterior tibial tendon }\end{array}$ \\
\hline
\end{tabular}

$\begin{array}{llll}\text { Miller } & \text { Repeated- } & 25 \text { participants } & \text { Orthotic device: } \\ \text { et al. } & \text { measures } & (13 & \text { constructed by using a } \\ 1996 & \text { intervention } & \text { male,12women) } & \text { plastic polymer and a firm } \\ \text { (United } & \text { studies } & \text { with } & \text { Plastizote medial heel } \\ \text { States of } & & \text { asymptomatic } & \text { wedge } \\ \text { America) } & & \text { pes planus } & \\ & & \text { Age: 18-40 year } & \end{array}$

$\begin{array}{ll}\text { Murley } & \text { Repeated- } \\ \text { et al. } & \text { measures } \\ 2010 & \text { intervention }\end{array}$

(Australia) studies

\section{0 subjects ( 15 male) with flatfeet} Age: $18-37$ years
Park et al. Repeated2017 (Republic intervention of Korea) studies
15 participants (college students) with flatfoot

\section{Customized FO:} a plaster cast impression was taken of each participant's feet, made from a semi-rigid $4 \mathrm{~mm}$ polypropylene thermoplastic shell and included features considered to minimize rearfoot pronation Modified prefabricated FO: three-quarter-length Formthotic made from dualdensity polyethylene foam

Functional foot orthotic (FFO): customized for each individual's foot shape and created with thermoplastic materials, high-density resistance elastic pad, cup sole for the plantar arch, low-elasticity pad for shock absorption in the heel, and ethylenevinylacetate (EVA)
Setting

\section{Outcomes/Measurement Main results}

Walking on treadmill at

low, normal and fast speed with the different insoles

No information

\section{Outcomes:}

tibia and the tarsal and metatarsal bones of the medial longitudinal arch (i.e., first metatarsal bone, and calcaneus)

Measurement:

Three-dimensional CT models; tibia and the tarsal and metatarsal bones of the medial longitudinal arch (i.e., first metatarsal bone, cuneiforms, navicular, talus, and calcaneus)

No information

Outcomes:

the dynamic GRFs (ground reaction forces) as a percentage of body weight in three directionsvertical, mediolateral, and anteroposterior-and the center of pressure by using an xand $y$-axis.

Measurement:

Walking across a standard force plate in 10 trials with and 10 trials without an orthotic device

\section{Outcomes:}

Comfort rating,

electromyographic activity, foot posture

Measurement:

VAS Scale (baseline and after 12 days),

Electromyogram, X-rays, under 4 conditions: Four experimental conditions were assessed: (i) barefoot, (ii) shoe only, (iii) a heatmoulded (modified) prefabricated foot orthosis, and (iv) a 20-degree inverted-style customized foot orthosis.

No information

Outcomes:

change in the pelvic angle Measurement:

six MX-F40 cameras, two OR6-7 force plates; walking on a previously fabricated Walkway before and after wearing the customized FFOs normal speed in the midfoot area is smaller when wearing PPRI than with flat insole

Therapeutic insoles: significantly suppressed the eversion of the talocalcaneal joint The subjects voiced no complaints of discomfort

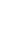

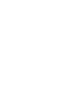


Table 2 Characteristics of included studies (Continued)

\begin{tabular}{|c|c|c|c|c|c|c|}
\hline $\begin{array}{l}\text { Author/ } \\
\text { year/ } \\
\text { country }\end{array}$ & Design & Population & Intervention & Setting & Outcomes/Measurement & Main results \\
\hline $\begin{array}{l}\text { et al. } \\
2020 \\
\text { (China) }\end{array}$ & $\begin{array}{l}\text { measures } \\
\text { intervention } \\
\text { studies }\end{array}$ & $\begin{array}{l}\text { (9 male) with } \\
\text { flatfoot }\end{array}$ & $\begin{array}{l}3 \mathrm{~cm} \text { thick medial arch } \\
\text { support and } 6 \text { inclined } \\
\text { medial forefoot posting, } \\
\text { made of fabric with } \\
\text { embedded cushioning } \\
\text { silicon at the heel region } \\
\text { Running shoes (Reebok } \\
\text { Run Supreme 4.0) }\end{array}$ & & $\begin{array}{l}\text { hip, patellofemoral, ankle, } \\
\text { medial and lateral } \\
\text { tibiofemoral joint contact } \\
\text { forces } \\
\text { Measurement: } \\
\text { 3D-motion capture system, } \\
4 \text { force plates under two } \\
\text { conditions: walking with } \\
\text { shoes and foot orthoses } \\
\text { and walking with shoes }\end{array}$ & $\begin{array}{l}\text { second peak } \\
\text { patellofemoral contact } \\
\text { force and the peak ankle } \\
\text { contact force were } \\
\text { significantly lower, } \\
\text { significantly reduced the } \\
\text { peak ankle eversion angle } \\
\text { and ankle eversion } \\
\text { moment, the peak knee } \\
\text { adduction moment } \\
\text { increased }\end{array}$ \\
\hline $\begin{array}{l}\text { Tang } \\
\text { et al. } \\
2015 \\
\text { (Taiwan) }\end{array}$ & $\begin{array}{l}\text { Controlled- } \\
\text { trial }\end{array}$ & $\begin{array}{l}\text { Intervention } \\
\text { Group: } \\
10 \text { subjects (age } \\
15-45 \text { ) with } \\
\text { flexible flatfoot } \\
\text { Control Group: } \\
15 \text { subjects } \\
\text { (age-matched) } \\
\text { without flatfoot }\end{array}$ & $\begin{array}{l}\text { Total contact insole: } \\
\text { Custom-made, total foot } \\
\text { contact with extended } \\
\text { heel guard to keep } \\
\text { subtalar joints in neutral } \\
\text { position, forefoot medial } \\
\text { posting, double-layer com- } \\
\text { position with superficial } \\
\text { PPT and semi rigid plasto- } \\
\text { zote base }\end{array}$ & No information & $\begin{array}{l}\text { Outcomes: } \\
\text { rearfoot motion and } \\
\text { plantar pressure } \\
\text { redistribution } \\
\text { Measurement: } \\
\text { motion analysis system } \\
\text { under three test conditions } \\
\text { (walk with barefoot, walk } \\
\text { with sports shoes, and } \\
\text { walk with TCIFMP and } \\
\text { sports shoes) }\end{array}$ & $\begin{array}{l}\text { Total contact insole: tends } \\
\text { to reduce valgus angle } \\
\text { and becomes statically } \\
\text { similar to normal subjects, } \\
\text { reduced foot pressure in } \\
\text { the hallux and heel area } \\
\text { compared to those } \\
\text { wearing only sports shoe. }\end{array}$ \\
\hline $\begin{array}{l}\text { Xu et al. } \\
2019 \\
\text { (China) }\end{array}$ & $\begin{array}{l}\text { Randomized- } \\
\text { controlled- } \\
\text { trial }\end{array}$ & $\begin{array}{l}\frac{\text { Intervention }}{\text { Group: }} \\
40 \text { subjects (20 } \\
\text { males, } 20 \\
\text { females) with } \\
\text { flexible flatfoot } \\
\text { Age: } 26-55 \\
\text { Weight: } 63.37 \text { ( } \pm \\
12.52) \mathrm{kg} \\
\text { Control Group: } \\
40 \text { subjects (20 } \\
\text { males, } 20 \\
\text { females) with } \\
\text { flexible flatfoot } \\
\text { Age: } 26-60 \text { years } \\
\text { Weight: } 67.18 \text { ( } \pm \\
\text { 10.72) kg }\end{array}$ & $\begin{array}{l}\text { Individually designed } \\
\text { insoles } \\
\text { D print insoles with } \\
\text { standardize shoes } \\
\text { Customized insoles } \\
\text { Standardize shoes with } \\
\text { customized ethylene vinyl } \\
\text { acetate (EVA) insoles }\end{array}$ & $\begin{array}{l}\text { Norman Bethune } \\
\text { Second Hospital } \\
\text { of Jilin University }\end{array}$ & $\begin{array}{l}\text { Outcomes: } \\
\text { VAS was measured to } \\
\text { measure comfort at } 0 \text { and } \\
8 \text { weeks } \\
\text { Measurement: } \\
\text { Footscan was used to } \\
\text { measure plantar pressure } \\
\text { under three test } \\
\text { conditions: barefoot, with } \\
3 \text { D insole and } \\
\text { standardized insole. } \\
3 \text { walking trials over a } 10 \\
\text { m walking distance, at a } \\
\text { speed of } 3.12 \text { ( } \pm 1.95 \text { ) km/ } \\
\text { h. } \\
\text { The insoles were worn } \\
\text { every day for } 6-8 \mathrm{~h} \text { over } 8 \\
\text { weeks. }\end{array}$ & $\begin{array}{l}\text { At week } 0 \text {, peak pressures } \\
\text { in the midfoot were } \\
\text { significantly lower ( } p< \\
0.05 \text { ) in the experimental } \\
\text { group compared to the } \\
\text { control group } \\
\text { At week } 8 \text {, peak pressures } \\
\text { in the midfoot were } \\
\text { significantly higher ( } p= \\
0.05 \text { ) in the experimental } \\
\text { group compared to the } \\
\text { control group } \\
\text { Comfort scores (measured } \\
\text { anhnad by VAS) were } \\
\text { significantly ( } p=0.05 \text { ) } \\
\text { lower in the experimental } \\
\text { group than in the control } \\
\text { group }\end{array}$ \\
\hline
\end{tabular}

after wearing the orthotic. Peng et al. [44] investigated the patellofemoral joint and the medial and lateral tibiofemoral joint. After wearing the foot orthoses, the second peak patellofemoral contact force and the peak contact force of the ankle were significantly lower. Foot orthoses also significantly reduced the peak eversion angle and the eversion moment of the ankle. The peak adduction moment of the knee was increased. Rearfoot motion and plantar pressure redistribution were measured in Tang et al. [48]. They reported that foot orthoses may reduce valgus angle and becomes statically similar to normal participants. Furthermore, a reduced foot pressure in the hallux and heel area when wearing foot orthoses was found compared to those wearing only sports shoes. Han et al. [40] reported that hindfoot ankle motion was less with both custom-made foot orthoses than with the normal foot orthoses. $\mathrm{Xu}$ et al. [39] measured three conditions: barefoot, with 3-D and standardized foot orthoses.

$30 \mathrm{~m}$ jump test, vertical jump test and $12 \mathrm{~min}$ Cooper-test Acak [47] measured BMI and weight and conducted a $30 \mathrm{~m}$ jump test, a vertical jump test, the 12 min Coopertest and Visual Analog Scale VAS. For the individually designed foot orthoses, they found statistically significant differences in all mentioned categories between pre- and post-test.

\section{Motion analysis}

Chen et al. [16] investigates spatio-temporal parameters as well as kinematic and kinetic data. For the custommade foot orthoses, the following was found: an increase in the peak ankle dorsiflexion angle and moment, a reduction in the peak ankle plantarflexion angle and 
Table 3 Risk of bias judgments by ROBINS-I domains

\begin{tabular}{|c|c|c|c|c|c|c|c|c|c|}
\hline \multirow[b]{2}{*}{ Author } & \multicolumn{9}{|c|}{ ROBINS-I domains } \\
\hline & Year & $\begin{array}{l}\text { Bias due to } \\
\text { confounding }\end{array}$ & $\begin{array}{l}\text { Bias in } \\
\text { selection of } \\
\text { participants }\end{array}$ & $\begin{array}{l}\text { Bias in } \\
\text { classification } \\
\text { of } \\
\text { intervention }\end{array}$ & $\begin{array}{l}\text { Bias due to } \\
\text { deviations from } \\
\text { intended } \\
\text { interventions }\end{array}$ & $\begin{array}{l}\text { Bias due } \\
\text { to } \\
\text { missing } \\
\text { data }\end{array}$ & $\begin{array}{l}\text { Bias in } \\
\text { measurement } \\
\text { of outcomes }\end{array}$ & $\begin{array}{l}\text { Bias in the } \\
\text { selection of } \\
\text { reported results }\end{array}$ & Overall \\
\hline $\begin{array}{l}\text { Acak } \\
\text { et al. }\end{array}$ & 2020 & $\mathrm{NI}$ & $\mathrm{NI}$ & Low risk & $\mathrm{Nl}$ & Low risk & Low risk & $\mathrm{NI}$ & $\mathrm{NI}$ \\
\hline $\begin{array}{l}\text { Aminian } \\
\text { et al. }\end{array}$ & 2013 & $\mathrm{NI}$ & $\mathrm{NI}$ & Low risk & $\mathrm{Nl}$ & $\mathrm{NI}$ & Low risk & $\mathrm{NI}$ & $\mathrm{NI}$ \\
\hline $\begin{array}{l}\text { Chen } \\
\text { et al. }\end{array}$ & 2010 & $\mathrm{NI}$ & $\mathrm{Nl}$ & Low risk & $\mathrm{Nl}$ & $\mathrm{NI}$ & Low risk & $\mathrm{NI}$ & $\mathrm{Nl}$ \\
\hline $\begin{array}{l}\text { Han } \\
\text { et al. }\end{array}$ & 2019 & $\mathrm{NI}$ & $\mathrm{NI}$ & Low risk & $\mathrm{Nl}$ & $\mathrm{NI}$ & Low risk & $\mathrm{NI}$ & $\mathrm{NI}$ \\
\hline $\begin{array}{l}\text { Jiang } \\
\text { et al. }\end{array}$ & 2021 & $\mathrm{NI}$ & $\mathrm{NI}$ & Low risk & $\mathrm{Nl}$ & $\mathrm{Nl}$ & Low risk & $\mathrm{NI}$ & $\mathrm{NI}$ \\
\hline $\begin{array}{l}\text { Kido } \\
\text { et al. }\end{array}$ & 2014 & $\mathrm{NI}$ & $\mathrm{NI}$ & Low risk & $\mathrm{Nl}$ & $\mathrm{Nl}$ & Low risk & $\mathrm{NI}$ & $\mathrm{NI}$ \\
\hline $\begin{array}{l}\text { Miller } \\
\text { et al. }\end{array}$ & 1996 & $\mathrm{NI}$ & $\mathrm{NI}$ & Low risk & $\mathrm{Nl}$ & $\mathrm{NI}$ & Low risk & $\mathrm{NI}$ & $\mathrm{NI}$ \\
\hline $\begin{array}{l}\text { Murley } \\
\text { et al. }\end{array}$ & 2010 & $\mathrm{NI}$ & $\mathrm{NI}$ & Low risk & $\mathrm{Nl}$ & $\mathrm{NI}$ & Low risk & $\mathrm{NI}$ & $\mathrm{NI}$ \\
\hline $\begin{array}{l}\text { Park } \\
\text { et al. }\end{array}$ & 2017 & $\mathrm{NI}$ & $\mathrm{NI}$ & Low risk & $\mathrm{Nl}$ & $\mathrm{NI}$ & Low risk & $\mathrm{NI}$ & $\mathrm{NI}$ \\
\hline $\begin{array}{l}\text { Peng } \\
\text { et al. }\end{array}$ & 2020 & $\mathrm{NI}$ & $\mathrm{NI}$ & Low risk & $\mathrm{Nl}$ & $\mathrm{NI}$ & Low risk & $\mathrm{NI}$ & $\mathrm{NI}$ \\
\hline $\begin{array}{l}\text { Tang } \\
\text { et al. }\end{array}$ & 2015 & $\mathrm{NI}$ & $\mathrm{NI}$ & Low risk & $\mathrm{Nl}$ & Low risk & Low risk & $\mathrm{NI}$ & $\mathrm{NI}$ \\
\hline
\end{tabular}

NI: no information

moment as well as an increase in the peak knee varus moment. Kido et al. [34] examines tibia, tarsal and metatarsal bones and medial longitudinal arch. The therapeutic foot orthoses significantly suppressed the eversion of the talocalcaneal joint.

\section{Dynamic ground reaction forces}

Miller [41] measured dynamic ground reaction forces (GRFs) in three directions: vertical, mediolateral and anteroposterior. The orthotic device reduces vertical and anteroposterior GRFs in the early stages of the stance phase during gait cycle.

\section{Electromyography}

In the study conducted by Murley et al. [42] electromyographic activity and foot posture was measured and the prefabricated foot orthosis showed a significant effect.

\section{Discussion}

The aim of this review was to summarize the evidence of foot orthoses in adults with flatfoot. Altogether, twelve studies could be included in this review. However, only one of these was a randomised controlled trial. Studies investigated different foot orthoses, such as custom-made foot orthoses [16, 39, 42-48], uniformly manufactured foot orthoses $[34,40]$ and semi-rigid foot orthoses [41]. None of the studies gave information about the selection of foot orthoses for the treatment of flatfoot. Additionally, authors used inconsistent terminology for the terms 'orthotic device' and 'foot orthoses'. For example, some studies used the term orthotic device $[40,41,43]$ when referring to foot orthoses.

Studies used different methods for the diagnosis of flatfoot in participants. One reason for this could be the lack of a standardized framework for flatfoot diagnosis [52-54].

A guideline should give advice for the selection of foot orthoses $[52,55]$. Compared to our study, similar results were found in reviews of the evidence for non-surgical interventions for pediatric flatfoot $[52,55]$. In this context, it should be mentioned that in Australia there is a guideline from the year 1998 for the prescription of foot orthoses from Petchell et al. [56] and from the year 2014 from Banwell et al. [23] that regulates the prescription of custom-made insoles for adult flatfoot. In Germany, there is currently no guideline for the provision of foot orthoses for adults with flatfoot.

The studies included provided little information in relation to how participants were recruited. Furthermore, no information was given on the severity of participants' 
symptoms. The majority of participants may have felt healthy and had no pain or other complaints. Banwell et al. [54] stated that it would be more appropriate to investigate the effectiveness of foot orthoses within a population recognizing symptoms.

The studies included assessed different outcomes and due to inconsistent outcome measurement, results are difficult to interpret. It is noteworthy that only two studies [34, 39] assessed the comfort of wearing the foot orthoses. The user's comfort should certainly be considered, as discomfort may be an important factor influencing patient's adherence. Furthermore, most of the included studies lack information on wearing time or when the measurements were conducted. Consequently, the comparability is low. Only one study reported on the observation period [42].

Although all studies found positive impacts, results must be interpreted with caution. We only found one randomised controlled trial evaluating the effectiveness of foot orthoses for patients with flatfoot. Most of the studies $(n=9)$ were repeated-measures intervention studies. In this design, participants are measured two or more times on the same variable, are given different treatments and measurements are taken after each one. This means that each participant will act as their own control $[57,58]$.

Due to a lack of information in several studies, no conclusive statement can be made about risk of bias. The studies which evaluate the effect of foot orthoses are predominantly repeated-measures intervention studies. The low number of randomised controlled trials leads to a lack of evidence. This result is consistent with the findings of Banwell et al. [54], who also found predominantly repeated-measure intervention studies. Additionally, the reporting quality of studies is rather low and important information about study methodology is missing.

Two $[16,41]$ studies out of twelve provided no information about any conflicts of interest. Two studies [34, 42] received funding but did not declare any conflict of interest.

Other reviews $[55,59]$ also reported that there is no strong evidence regarding the effect of foot orthoses.

The results of this review are consistent with the results of other reviews [52, 54, 59] addressing the evidence for foot orthoses. Based on the available evidence and the absence of clinical guidelines, the routine prescription of foot orthoses for flat feet in adults needs to be reconsidered [23, 60]. Unfortunately, we are unable to draw firm conclusions due to the lack of methodological and reporting quality of the included studies. Furthermore, randomised trials with foot orthoses under standardized conditions need to be conducted, as these are the gold standard in testing evidence for efficacy [61].
To minimise bias, the whole screening and data extraction process was conducted by two independent researchers. Furthermore, we contacted study authors and experts in the field for unpublished studies.

A limitation of this review is that only a small number of studies were suitable for inclusion and the studies included almost all used a repeated-measure intervention design. Because there is no separate tool to assess methodological quality of repeated-measure intervention studies, the ROBINS-I tool was used. The methodological quality of all of the included studies was determined to be unclear due to the insufficient quality of reporting. A further limitation of this review is as follows: due to the lack of randomised-controlled trials, the potential for confounding and bias could not be ruled out. A comparison of the studies was not possible because all of the included studies measured different outcomes, using different measurement methods.

Because of this number of limitations, no clear conclusion regarding effectiveness and effects of foot orthoses can be drawn and it is not possible to make a clear recommendation for the use of foot orthoses in adults.

\section{Conclusions}

As appropriate studies were not detected in our searches, no firm conclusions can be drawn on the effects and effectiveness of foot orthoses for patients with flatfoot. However, there are several limitations, such as the inconsistent population of participants studies, the various foot orthoses used, the different outcomes and the fact that no temporal information about the wearing of the foot orthoses was described. Evidence in terms of diagnostics, indication and the prescription of different kinds of foot orthoses, as well as evidence concerning duration of therapy, is needed. To date, no firm conclusions can be drawn about the (positive) effects foot orthoses might have for patients with flatfoot. Against this background, the common prescription of foot orthoses in adults with flatfoot is surprising.

\section{Supplementary Information}

The online version contains supplementary material available at https://doi. org/10.1186/s13047-021-00499-z.

Additional file 1: Table S1. Search terms to select the studies.

\section{Acknowledgements}

Authors would like to thank native speaker Frances Barrett for her suggestions regarding our manuscript.

\section{Authors' contributions}

Study concept and design: MH, JS. Literature Search: MH, DW. Analysis and interpretation of data: $\mathrm{MH}, \mathrm{DW}, \mathrm{JS}$. Drafting of the manuscript: $\mathrm{MH}, \mathrm{DW}, \mathrm{JS}$. All authors read and approved the final manuscript.

Funding

Open Access funding enabled and organized by Projekt DEAL. 


\section{Availability of data and materials}

Not applicable.

\section{Declarations}

Ethics approval and consent to participate

Not applicable.

\section{Consent for publication}

Not applicable.

\section{Competing interests}

The authors declare that they have no competing interests.

Received: 1 September 2021 Accepted: 15 November 2021

\section{Published online: 29 November 2021}

\section{References}

1. Yurt $Y$, Sener $G$, Yakut $Y$. The effect of different foot orthoses on pain and health related quality of life in painful flexible flat foot: a randomized controlled trial. Eur J Phys Rehabil Med. 2019;55(1):95-102. https://doi.org/1 0.23736/S1973-9087.18.05108-0.

2. Moreira E, Jones A, Oliveira HA, Jennings F, Fernandes A, Natour J. Effectiveness of insole use in rheumatoid feet: a randomized controlled trial. Scand J Rheumatol. 2016;45(5):363-70. https://doi.org/10.3109/03009742.201 5.1110198.

3. Unfallchirurgie BfOu. Die Verordnung orthopädischer Einlagen für Konfektionsschuhe. Germany: Berufsverband für Orthopädie und Unfallchirurgie; 2020. Available from: https://www.bvou.net

4. Myerson MS. Adult acquired flatfoot deformity: treatment of dysfunction of the posterior tibial tendon. Instr Course Lect. 1997;46:393-405.

5. Van DB, Sangeorzan BJ. Biomechanics and pathophysiology of flat foot. Foot Ankle Clin. 2003;8(3):419-30. https://doi.org/10.1016/S1083-7515(03 )00084-6.

6. Bertani A, Cappello A, Benedetti M, Simoncini L, Catani F. Flat foot functional evaluation using pattern recognition of ground reaction data. Clin Biomech. 1999;14(7):484-93. https://doi.org/10.1016/50268-0033 (98)90099-7.

7. Clement D, Taunton J, Smart G. Achilles tendinitis and peritendinitis: etiology and treatment. Am J Sports Med. 1984;12(3):179-84. https://doi org/10.1177/036354658401200301.

8. Franco AH. Pes cavus and pes planus: analyses and treatment. Phys Ther. 1987;67(5):688-94. https://doi.org/10.1093/ptj/67.5.688.

9. Kaufman KR, Brodine SK, Shaffer RA, Johnson CW, Cullison TR. The effect of foot structure and range of motion on musculoskeletal overuse injuries. Am J Sports Med. 1999;27(5):585-93. https://doi.org/10.1177/036354659902 70050701

10. Messier SP, Pittala KA. Etiologic factors associated with selected running injuries. Med Sci Sports Exerc. 1988;20(5):501-5.

11. Arain A, Harrington MC, Rosenbaum AJ. Adult acquired flatfoot (AAFD). Germany: Berufsverband für Orthopädie und Unfallchirurgie; 2019.

12. Hadfield MH, Snyder JW, Liacouras PC, Owen JR, Wayne JS, Adelaar RS. Effects of medializing calcaneal osteotomy on Achilles tendon lengthening and plantar foot pressures. Foot Ankle Int. 2003;24(7):523-9. https://doi. org/10.1177/107110070302400703.

13. Kohls-Gatzoulis J, Woods B, Angel J, Singh D. The prevalence of symptomatic posterior tibialis tendon dysfunction in women over the age of 40 in England. Foot Ankle Surg. 2009;15(2):75-81. https://doi.org/10.1016/ j.fas.2008.08.003.

14. Ikpeze TC, Brodell JD Jr, Chen RE, Oh I. Evaluation and treatment of posterior tibialis tendon insufficiency in the elderly patients. Geriatr Surg Rehabil. 2019;10:2151459318821461. https://doi.org/10.1177/215145931 8821461.

15. Wapner KL, Chao W. Nonoperative treatment of posterior tibial tendon dysfunction. Clin Orthop Relat Res. 1999;365:39-45. https://doi.org/10.1097/ 00003086-199908000-00005.

16. Chen Y-C, Lou S-Z, Huang C-Y, Su F-C. Effects of foot orthoses on gait patterns of flat feet patients. Clin Biomech. 2010;25(3):265-70. https://doi. org/10.1016/j.clinbiomech.2009.11.007.

17. Alvarez RG, Marini A, Schmitt C, Saltzman CL. Stage I and II posterior tibial tendon dysfunction treated by a structured nonoperative management protocol: an orthosis and exercise program. Foot Ankle Int. 2006;27(1):2-8. https://doi.org/10.1177/107110070602700102.

18. Kulcu DG, Yavuzer G, Sarmer S, Ergin S. Immediate effects of silicone insoles on gait pattern in patients with flexible flatfoot. Foot Ankle Int. 2007:28(10): 1053-6. https://doi.org/10.3113/FAl.2007.1053.

19. Bishop C, Thewlis D, Hillier S. Custom foot orthoses improve first-step pain in individuals with unilateral plantar fasciopathy: a pragmatic randomised controlled trial. BMC Musculoskelet Disord. 2018;19(1):222. https://doi.org/1 0.1186/s12891-018-2131-6.

20. Lewinson RT, Madden R, Killick A, Wannop JW, Preston Wiley J, Lun VMY, et al. Foot structure and knee joint kinetics during walking with and without wedged footwear insoles. J Biomech. 2018;73:192-200. https://doi. org/10.1016/j.jbiomech.2018.04.006.

21. Spitzenverband Bund der Krankenkassen (GKV-Spitzenverband), 2. Bericht des GKV-Spitzenverbandes üder die Entwicklung der Mehrkostenvereinbarungen für Versorgungen mit Hilfsmittelleistungen. 2020.

22. Strumann C, Emcke T, Flägel K, Steinhäuser J. Regionale Unterschiede zwischen Fachärztinnen und Fachärzten für Allgemeinmedizin und hausärztlich tätigen Internistinnen und Internisten in der hausärztlichen Versorgung. Zeitschrift für Evidenz, Fortbildung und Qualität im Gesundheitswesen. 2020;150:88-95. https://doi.org/10.1016/j.zefq.2020.01. 005.

23. Banwell HA, Mackintosh S, Thewlis D, Landorf KB. Consensus-based recommendations of Australian podiatrists for the prescription of foot orthoses for symptomatic flexible pes planus in adults. J Foot Ankle Res. 2014;7(1):1-13. https://doi.org/10.1186/s13047-014-0049-2.

24. Johanson MA, Donatelli R, Wooden MJ, Andrew PD, Cummings GS. Effects of three different posting methods on controlling abnormal subtalar pronation. Phys Ther. 1994;74(2):149-58. https://doi.org/10.1093/ptj/74.2.149.

25. Seo KC, Park KY. The effects of foot orthosis on the gait ability of college students in their 20s with flat feet. J Phys Ther Sci. 2014;26(10):1567-9. https://doi.org/10.1589/jpts.26.1567.

26. Leung A, Mak A, Evans J. Biomechanical gait evaluation of the immediate effect of orthotic treatment for flexible flat foot. Prosthetics Orthot Int. 1998; 22(1):25-34. https://doi.org/10.3109/03093649809164454.

27. Queen RM, Mall NA, Nunley JA, Chuckpaiwong B. Differences in plantar loading between flat and normal feet during different athletic tasks. Gait Posture. 2009;29(4):582-6. https://doi.org/10.1016/j.gaitpost.2008.12.010.

28. Williams DS, McClay IS. Measurements used to characterize the foot and the medial longitudinal arch: reliability and validity. Phys Ther. 2000;80(9):86471. https://doi.org/10.1093/ptj/80.9.864.

29. Hamel J, Kinast C. Der TMT-index zur radiologischen Quantifizierung von Planovalgus-Deformitäten. Fuß \& Sprunggelenk. 2006;4(4):221-6. https://doi. org/10.1007/s10302-006-0244-y.

30. Saltzman CL, Brandser EA, Berbaum KS, DeGnore L, Holmes JR, Katcherian DA, et al. Reliability of standard foot radiographic measurements. Foot Ankle Int. 1994;15(12):661-5. https://doi.org/10.11 77/107110079401501206

31. Saltzman CL, Nawoczenski DA, Talbot KD. Measurement of the medial longitudinal arch. Arch Phys Med Rehabil. 1995;76(1):45-9. https://doi.org/1 0.1016/S0003-9993(95)80041-7.

32. Lee MS, Vanore JV, Thomas JL, Catanzariti AR, Kogler G, Kravitz SR, et al. Diagnosis and treatment of adult flatfoot. J Foot Ankle Surg. 2005;44(2):78113. https://doi.org/10.1053/j.jfas.2004.12.001.

33. Gutteck N, Schilde S, Delank K, Arbab D. Ätiologie, Pathogenese, Klinik, Diagnostik und konservative Therapie des adulten erworbenen Plattfußes. Orthopade. 2020;49(11):1-11. https://doi.org/10.1007/s00132020-03995-5.

34. Kido M, Ikoma K, Hara Y, Imai K, Maki M, Ikeda T, et al. Effect of therapeutic insoles on the medial longitudinal arch in patients with flatfoot deformity: a three-dimensional loading computed tomography study. Clin Biomech. 2014;29(10):1095-8. https://doi.org/10.1016/j.clinbiomech.2014.10.005.

35. Cumpston M, Li T, Page MJ, Chandler J, Welch VA, Higgins JP, Thomas J. Updated guidance for trusted systematic reviews: a new edition of the Cochrane Handbook for Systematic Reviews of Interventions. CochraneDatabase Syst Rev. 2019;10:ED000142. https://doi.org/10.1002/14 651858.ED000142.

36. Liberati A, Altman DG, Tetzlaff J, Mulrow C, Gøtzsche PC, loannidis JP, et al. The PRISMA statement for reporting systematic reviews and meta-analyses of studies that evaluate health care interventions: explanation and 
elaboration. PLoS Med. 2009;6(7):e1000100. https://doi.org/10.1371/journal. pmed.1000100.

37. NCT. Effects of Exercise and Insole on Foot Posture, Balance and Plantar Pressure Variables in Individuals With Pes Planus (Study Protocol) 2019 Available from: https://clinicaltrials.gov/show/NCT04179591.

38. NCT. Effect of Foot Muscles Training and Foot Orthosis on the Medial Arch in Flatfoot Subjects (Study Protocol) 2020 . Available from: https://linicaltria Is.gov/show/NCT04480177.

39. Xu R, Wang Z, Ren Z, Ma T, Jia Z, Fang S, et al. Comparative study of the effects of customized 3D printed insole and prefabricated insole on plantar pressure and comfort in patients with symptomatic flatfoot. Med Sci Monit. 2019;25:3510-9. https://doi.org/10.12659/MSM.916975.

40. Aminian G, Safaeepour Z, Farhoodi M, Pezeshk AF, Saeedi H, Majddoleslam B. The effect of prefabricated and proprioceptive foot orthoses on plantar pressure distribution in patients with flexible flatfoot during walking. Prosthetics Orthot Int. 2013;37(3):227-32. https://doi.org/10.1177/0309364 612461167.

41. Miller CD, Laskowski ER, Suman VJ. Effect of corrective rearfoot orthotic devices on ground reaction forces during ambulation. Mayo Clinic Proce: Elsevier; 1996.

42. Murley GS, Landorf KB, Menz HB. Do foot orthoses change lower limb muscle activity in flat-arched feet towards a pattern observed in normalarched feet? Clin Biomech. 2010;25(7):728-36. https://doi.org/10.1016/j. clinbiomech.2010.05.001.

43. Park K. Effects of wearing functional foot orthotic on pelvic angle among college students in their 20s with flatfoot. J Phys Ther Sci. 2017;29(3):438-41. https://doi.org/10.1589/jpts.29.438.

44. Peng $Y$, Wong DW-C, Wang $Y$, Chen TL-W, Tan Q, Chen Z, et al. Immediate effects of medially posted insoles on lower limb joint contact forces in adult acquired flatfoot: a pilot study. Int J Environ Res Public Health. 2020;17(7): 2226. https://doi.org/10.3390/ijerph17072226.

45. Han K, Bae K, Levine N, Yang J, Lee JS. Biomechanical effect of foot orthoses on Rearfoot motions and joint moment parameters in patients with flexible flatfoot. Med Sci Monit. 2019;25:5920-8. https://doi.org/10.12659/MSM.91 8782.

46. Jiang Y, Wang D, Ying J, Chu P, Qian Y, Chen W. Design and Preliminary Validation of Individual Customized Insole for Adults with Flexible Flatfeet Based on the Plantar Pressure Redistribution. Sensors (Basel). 2021;21(5): 1780.

47. Açak M. The effects of individually designed insoles on pes planus treatment. Sci Rep. 2020;10(1):1-6. https://doi.org/10.1038/s41598-02076767-y.

48. Tang SF-T, Chen C-H, Wu C-K, Hong W-H, Chen K-J, Chen C-K. The effects of total contact insole with forefoot medial posting on rearfoot movement and foot pressure distributions in patients with flexible flatfoot. Clin Neurol Neurosurg. 2015;129:S8-S11. https://doi.org/10.1016/ S0303-8467(15)30004-4.

49. Cavanagh PR, Rodgers MM. The arch index: a useful measure from footprints. J Biomech. 1987;20(5):547-51. https://doi.org/10.1016/0021-92 90(87)90255-7.

50. Deutschland C. Bewertung des Verzerrungsrisikos von systematischen Übersichtsarbeiten:ein Manual für die Leitlinienerstellung. Deutschland: Cochrane Deutschland Stiftung (CDS): 2017. Available from: https://www. cochrane.de

51. Sterne JA, Hernán MA, Reeves BC, Savović J, Berkman ND, Viswanathan M, et al. ROBINS-l: a tool for assessing risk of bias in non-randomised studies of interventions. BMJ. 2016;355:i4919. https://doi.org/10.1136/bmj.i4919.

52. Evans AM, Rome K. A Cochrane review of the evidence for non-surgical interventions for flexible pediatric flat feet. Eur J Phys Rehabil Med. 2011; 47(1):69-89.

53. Menz HB. Foot orthoses: how much customisation is necessary. J Foot Ankle Res. 2009;2(1):1-3. https://doi.org/10.1 186/1757-1146-2-23.

54. Banwell HA, Mackintosh S, Thewlis D. Foot orthoses for adults with flexible pes planus: a systematic review. J Foot Ankle Res. 2014;7(1):1-18. https://doi. org/10.1186/1757-1146-7-23.

55. Dars S, Uden H, Banwell HA, Kumar S. The effectiveness of non-surgical intervention (foot orthoses) for paediatric flexible pes planus: a systematic review: update. PLoS ONE. 2018;13(2):e0193060. https://doi.org/10.1371/ journal.pone.0193060.

56. Petchell A, Keenan A-M, Landorf K. National clinical guidelines for podiatric foot orthoses. AustralsJ Podiar Med. 1998;32(3):97-104.
57. Huck SW, McLean RA. Using a repeated measures ANOVA to analyze the data from a pretest-posttest design: a potentially confusing task. Psychol Bull. 1975;82(4):511-8. https://doi.org/10.1037/h0076767.

58. Singh V, Rana RK, Singhal R. Analysis of repeated measurement data in the clinical trials. J Ayurveda integr Med. 2013;4(2):77-81. https://doi.org/10.41 03/0975-9476.113872.

59. Jane MacKenzie A, Rome K, Evans AM. The efficacy of nonsurgical interventions for pediatric flexible flat foot: a critical review. J Pediatr Orthop. 2012;32(8):830-4. https://doi.org/10.1097/BPO.0b013e3182648c95.

60. Chapman LS, Redmond AC, Landorf KB, Rome K, Keenan A-M, Waxman R, Alcacer-Pitarch B, Siddle HJ, Backhouse MR A survey of foot orthoses prescription habits amongst podiatrists in the UK, Australia and New Zealand. J Foot Ankle Res 2018;11(1):1-11, 64, https://doi.org/10.1186/s1304 7-018-0304-z.

61. Bundesärztekammer, Berlin, Deutschland. Placebo in der Medizin. 2010.

\section{Publisher's Note}

Springer Nature remains neutral with regard to jurisdictional claims in published maps and institutional affiliations.

\section{Ready to submit your research? Choose BMC and benefit from:}

- fast, convenient online submission

- thorough peer review by experienced researchers in your field

- rapid publication on acceptance

- support for research data, including large and complex data types

- gold Open Access which fosters wider collaboration and increased citations

- maximum visibility for your research: over $100 \mathrm{M}$ website views per year

At BMC, research is always in progress.

Learn more biomedcentral.com/submissions 